застосування належних способів цивільно-правового захисту загалом можуть бути кваліфіковані або як причина порушення суб'єктивних прав та інтересів особи (спосіб заподіяння шкоди зокрема), або як обставини, що звільняють заінтересовану особу від відповідальності (непереборна сила, випадок, самозахист тощо), або як підстава для припинення правовідносин через неможливість реалізації їх змісту, або як істотна зміна обставин, що має бути взята до уваги 3 метою додержання засад справедливості, розумності й добросовісності при визначення правового становища сторін певних правовідносин.

\title{
Література:
}

1. Основні принципи і керівні положення щодо права на правовий захист i відшкодування шкоди для жертв грубих порушень міжнародних норм у сфері прав людини і серйозних порушень міжнародного гуманітарного права (схвалені Комісією з прав людини $\mathrm{OOH}$ 25.07.2005). URL: http://zakon3.rada.gov.ua/laws/show/995_e53 (дата звернення: 27.10.2020).

DOI https://doi.org/10.30525/978-9934-588-92-1-40

\section{ПРОТИПРАВНІСТЬ ЯК ОБ'СКТИВНА УМОВА ВИНИКНЕННЯ ЦИВІЛЬНО-ПРАВОВОЇ ВІДПОВІДАЛЬНОСТІ ЗА ПОРУШЕННЯ АВТОРСЬКОГО ПРАВА}

\author{
Ромась Д. С. \\ аспірант кафедри циивільного права та прочесу \\ Хмельницького університету управління та права \\ імені Леоніда Юзькова \\ м. Хмельницький, Украӥна
}

Підставою виникнення цивільно-правової відповідальності $\epsilon$ цивільне правопорушення, для якого характерна сукупність об'єктивних та суб'єктивних умов для покладення відповідальності на порушника. Так, С.Д. Гринько об'єктивні умови пов'язує з діяльністю людини у зовнішньому світі, а суб'єктивну умову характеризує як вольовий і свідомий людський фактор, який зумовив діяльність людини у зовнішньому світі [1, с. 224]. 
Однією 3 об'єктивних умов виникнення цивільно-правової відповідальності є протиправність поведінки, яка включає в себе протиправну дію або бездіяльність. До прикладу, I.С. Канзафарова протиправними називає «дії (бездіяльність), які порушують права та обов'язки, закріплені чи санкціоновані нормами цивільного права, а також ті, які хоча і не передбачені конкретною нормою права, але суперечать загальним засадам цивільного законодавства» [2, с. 223].

Протиправна поведінка у сфері авторського права має свою специфіку. Зокрема, необхідною передумовою порушення особистого авторського права $\epsilon$ дії, які загрожують особистим правам автора, або такі, що порушують ці права [3, с. 117].

На нашу думку, порушення авторського права знаходить свій вияв через дії, і рідко через бездіяльність. Згідно зі ст. 50 Закону України «Про авторське право i суміжні права» найпоширенішими протиправними діями при порушенні авторського права є: 1) дії, які порушують особисті немайнові та майнові права суб'єктів авторського права; 2) піратство у сфері авторського права і (або) суміжних прав; 3) плагіат - оприлюднення (опублікування), повністю або частково, чужого твору під іменем особи, яка не $\epsilon$ автором цього твору; 4) камкординг, кардшейрінг тощо [4].

Вказані протиправні дії як об'єктивна умова виникнення цивільноправової відповідальності $\epsilon$ характерними виключно у випадку порушення авторського права.

Прикладом дій, які порушують особисті немайнові та майнові права суб'єктів авторського права, можуть бути перекручення, спотворення чи інша зміна твору або будь-яке інше посягання на твір, що може зашкодити честі і репутації автора (п. 4 ч. 1 ст. 14 Закону України «Про авторське право і суміжні права»).

Одним із видів порушення авторського права $є$ nіратство у сфері авторського права, яке включає в себе наступні протиправні дії: опублікування; відтворення, ввезення та вивезення через митну територію України контрафактних примірників творів та їх розповсюдження. При цьому піратство та контрафакцію часто ототожнюють, а тому O.I. Харитонова для розмежування піратства та контрафакції пропонує застосовувати два критерії: якість механічного відтворення, яка при контрафакції залишається незмінною порівняно 3 оригіналом, а також прагнення контрафактора ввести в оману споживача при розповсюджені контрафактних примірників, та відсутність такого наміру при піратстві внаслідок явної підробки примірнику, що містить об’єкти авторсько права [5, с. 224]. Таким чином, контрафакція (як складова піратства) також визнається 168 
протиправною дією, що $є$ умовою виникнення цивільно-правової відповідальності за порушення авторського права.

Різновидом протиправної дії як умови виникнення цивільноправової відповідальності за порушення авторського права є плагіат, а саме «оприлюднення (опублікування), повністю або частково, чужого твору під іменем особи, яка не $\epsilon$ автором цього твору» (ст. 1 Закону України «Про авторське право і суміжні права») [4]. Р.Б. Шишка зазначає, що плагіату властиві певні ознаки, які автор поділяє на основні та варіативні: до перших належить формальна ознака використання чужого витвору під власним іменем, зокрема його оприлюднення, що, зазвичай із суб'єктивної сторони, $є$ навмисним та усвідомленим. До других - відсутність посилання на першоджерело та вказівки на автора, якщо він відомий, створення твору з певним перефразуванням [6, с. 175].

Протиправними діями є також камкординг та кардшейрінг (ст. ст. 1, 50 Закону України «Про авторське право і суміжні права»). Законодавець дає визначення камкордингу як відеозапис аудіовізуального твору під час його публічної демонстрації без дозволу суб'єкта авторського права, в той час як кардшейрінгом $\epsilon$ забезпечення у будь-якій формі та в будьякий спосіб доступу до програми (передачі) організації мовлення, доступ до якої обмежений суб'єктом авторського права [4].

Таким чином, головною відмінністю камкордингу (записування відео) від кардшейрінгу (надання доступу) $є$ спосіб порушення авторського права: при камкордингу протиправною дією $\epsilon$ процес відеозапису, а при кардшейрінгу протиправною дією $є$ надання доступу до програм. Однак ознакою, яка об'єднує вказані поняття, є вчинення зазначених дій без дозволу суб'єкта авторського права.

Підсумовуючи усе зазначене вище, слід дійти висновку, що протиправною дією як об'єктивною умовою виникнення цивільноправової відповідальності є вчинення будь-яких дій, які порушують особисті немайнові та майнові права суб'єктів авторського права. При цьому, обов'язковою ознакою протиправності $є$ закріплення таких порушень у Законі України «Про авторське право і суміжні права».

\section{Література:}

1. Гринько С.Д. Деліктні зобов'язання римського приватного права: поняття, система, рецепція: монографія. Хмельницький: Хмельницький університет управління та права, 2012. 724 с.

2. Канзафарова Ілона Станіславівна Теоретичні основи цивільноправової відповідальності в Україні : дис. ... д- ра юрид. наук: 12.00.03 / 
НАН України; Інститут держави і права ім. В.М. Корецького. Київ, 2007. 453 с.

3. Кирилюк А.В. Правопорушення авторських прав у мережі Інтернет: поняття та види. Часопис иивілістики. 2016. № 22. C. $117-121$.

4. Закон України «Про авторське право i суміжні права» від 23.12.1993 р. № 3792-XII. Відомості Верховної Ради Украйни. 1994. № 13. Ст. 64.

5. Харитонова О.I. Порівняльно-правові дослідження піратства, контрафакції та плагіату за законодавством України та Польщі. Часопис ииивілістики. 2014. № 16. С. 222-226.

6. Шишка Р.Б. Плагіат та його прояви i небезпеки. Часопис Київського університету права. 2014. № 4. С. 170-175.

DOI https://doi.org/10.30525/978-9934-588-92-1-41

\title{
«АРХІТЕКТОНІКА» МЕХАНІЗМУ ПРАВОВОГО РЕГУЛЮВАННЯ СІМЕЙНИХ ВІДНОСИН
}

\author{
Чернега В. М. \\ кандидат юридичних наук, доиент, \\ доцент кафедри підприємницького та корпоративного права \\ Державного вищого навчального закладу «Київський національний \\ економічний університет імені Вадима Гетьмана» \\ м. Київ, Україна
}

Як зазначає Н. С. Кузнєцова, механізм правового регулювання «безпосередньо пов'язаний з ефективністю права та його інструментарію» $[1$, с. 18]. Тому неможливо не зупинитися на «архітектоніці» механізму правового регулювання сімейних відносин, яка донині в спеціальній літературі розлого не окреслена. Адже структура механізму правового регулювання переважно розглядається в працях цивільноправового спрямування. Йдеться про здобутки в цьому питанні таких українських учених: Н. С. Кузнєцової, I. С. Лукасевич-Крутник, В. В. Луця, В. В. Мазура, Н. В. Міловської, О. О. Отраднової, М. Д. Пленюк, С. О. Погрібного, I. Я. Сенюти, Р. I. Таш'яна, Н. В. Федорченко та ін. 